\title{
Ontogeny and morphological development of Tilapia (Oreochromis niloticus) larvae in Aceh Province, Indonesia
}

\author{
Ismarica Ismarica, Dedi Fazriansyah Putra*, and Ulfa Khairina \\ Department of Aquaculture, Faculty of Marine and Fisheries, Universitas Syiah Kuala, Banda Aceh, Indonesia
}

\begin{abstract}
Tilapia (Oreochromis niloticus) is one type of fish that has high economic value and is widely consumed by the community. Therefore, the growth and development of tilapia larvae need to be considered. This study aims to determine the growth and development of tilapia larvae. The parameters in this study were observations of total larval length (TL), daily growth rate (LPH), and morphology of tilapia larvae. This research was conducted for 30 days. Measurements of total length growth and morphological development of tilapia larvae were measured on days 1, 5, 10, 15, 20, 25 and 30 DAH (Days After Hatching). Data were analysed descriptively. The results of this study showed that the growth of tilapia larvae from day 1 to day 30 increased. The development of tilapia larvae in the yolk sac phase occurred on day 1-7 and the transition phase (from endogenous feeding to exogenous feeding) occurred on day 6-7 DAH, and on day 8 the yolk sac had been exhausted. The morphological development of tilapia larvae began to form completely on day $10 \mathrm{DAH}$.
\end{abstract}

\section{Introduction}

Tilapia (Oreochromis niloticus) is a type of fish with high economic value and is largely consumed by the society. According to [1], Tilapia (Oreochromis niloticus L.) is one of the freshwater fish that has a high selling value. Oreochromis niloticus is one of the economic commodities in Indonesia [2]. Tilapia cultivation is much done by the community. However, the cultivators have some problems on the larval stage maintainance. In hatchery, larval stage is one of the critical factors, in which there are still many obstacles in increasing the growth [3]. The larval stage is divided into 2 stages, namely the pralarva and postlarva stages. According to [4], at the prelarva stage the fish body is still transparent and then at the postlarva stage the fish body has developed to be complete. [5] revealed that immature larval growth resulted in mortality. The mortality that occurs is due to the immature morphology of fish larvae so that the larvae are susceptible to disease, and the critical period of larvae during the transition from egg yolk to food from outside (exsogenous feeding).

Increased growth and development of larvae is very important for larval survival and success in cultivation. The early development of fishes is usually regarded as a steady accumulation of small changes to produce an adult phenotype [6]. According to [7], The growth rate of tilapia larvae was greater in larvae reared at a temperature of $31^{\circ} \mathrm{C}$ (day): $25^{\circ} \mathrm{C}$ (night) due to increased synchronization of digestion and feed utilization. Increased growth of tilapia larvae is associated with high feed conversion efficiency [8]. In addition to growth, the rapid development of larval morphology is also important. According to [9] that rearing at $30^{\circ} \mathrm{C}$ has faster embryo development and hatching time for orange-spotted grouper eggs. Optimal growth and fastest morphogenesis in the interaction treatment of $30^{\circ} \mathrm{C}$ temperature with $3 \%$ salinity [10]. Therefore, this study of growth and morphological development of tilapia aims to determine the growth and morphological development that supports the success of rearing tilapia larvae.

\section{Materials and Methods}

\subsection{Tilapia larvae spawning and rearing}

Parent male and female tilapia were obtained from the Regional Technical Implementation Unit or Unit Pelaksana Teknis Daerah (UPTD) Fish Seed Center or Balai Benih Ikan (BBI) Lukup Badak, Pegasing District, Central Aceh. In tilapia spawning, the feed used was added with vitamin $\mathrm{E}$ with the aim of stimulating the gonad maturity of the tilapia parent. The vitamin E used were as much as 5 grams $/ 1 \mathrm{~kg}$ of feed. Vitamin E was first dissolved with alcohol then mixed into the feed, then dried. Feeding was carried out for 14 days with a frequency of 2 times. The spawning container were a $3 \mathrm{~m}$ x $5 \mathrm{~m}$ concrete pond, and a $30 \mathrm{~cm}$ x $20 \mathrm{~cm}$ x $25 \mathrm{~cm}$ pond as larval rearing container filled with $10 \mathrm{~L}$ of water and equipped with aeration. The natural feed given in the early stages of larvae comes from green water in tilapia rearing ponds with a frequency of feeding 3 times a day. Furthermore, feeding with flour pellets was carried out.

\footnotetext{
*Corresponding author : dfputra@unsyiah.ac.id
} 


\subsection{The Total Length of Larvae}

The total length of larvae was measured on day $1,5,10$, $15,20,25$ and $30 \mathrm{DAH}$ using a digital calliper (mm) with an accuracy of $\pm 0.2 \mathrm{~mm}$. 5 larvae were taken randomly every day to measure the total body length, then the average total length was calculated with \pm standard deviation (SD). Furthermore, the pattern of growth in the length of tilapia fish larvae was described using Microsoft Excel.

The daily growth rate (LPH) was calculated according to [11]:

\section{$\mathrm{LPH}=\mathrm{Lt}-\mathrm{Lo} / \mathrm{t}$}

Information:

$\mathrm{LPH}=$ Daily growth rate $(\mathrm{mm} /$ day $)$,

$\mathrm{Lt}=$ Average total length at the end of the study $(\mathrm{mm})$

Lo = Average total length at the beginning of the study (mm)

\subsection{Larvae Morphological Observations}

Sampling of larvae for morphological analysis was carried out on day 1, 5, 10, 15, 20, 25 and 30 DAH (Days After Hatching). A total of 15 samples were taken on each observation day from the larval rearing container, then put into a sample bottle and preserved with $10 \%$ NBF (Neutral Buffer Formalin). Morphological analysis, 5 larvae samples were taken randomly from the sample bottle, then observed under a stereo microscope and photos were taken.

\section{Results and Discussion}

\subsection{The total Length of Tilapia (Oreochromis niloticus) Larvae}

Results of the daily growth rate of tilapia larvae was 0.6 $\mathrm{mm} /$ day. Newly hatched larvae had an average total length of $7.3 \pm 0.7 \mathrm{~mm}$ at $1 \mathrm{DAH}$, and the average total length at $30 \mathrm{DAH}$ was $26 \pm 1.1 \mathrm{~mm}$. Growth in larval length for 30 days is shown in (Figure 1).

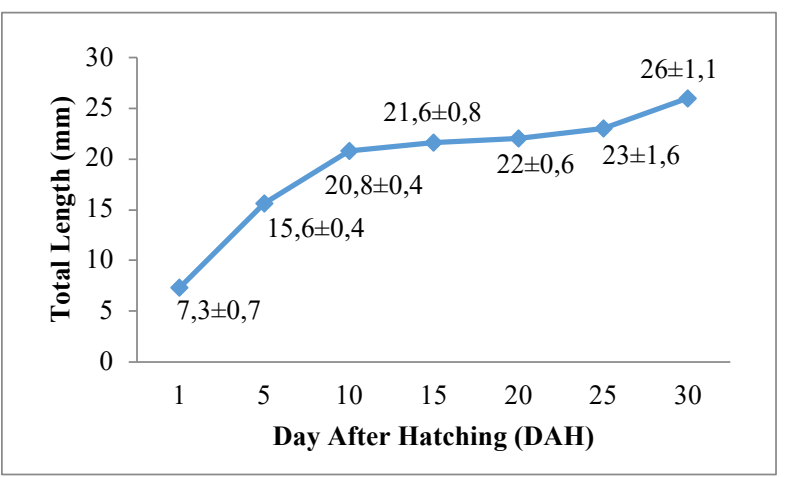

Fig. 1. The growth pattern of tilapia larvae length from 1

\section{DAH to $30 \mathrm{DAH}$}

The results of the growth of tilapia larvae length from the first day of hatching to $30 \mathrm{DAH}$ increased along with the addition of the age of tilapia larvae. In Figure 1, the graph shows that the growth pattern of tilapia larvae length is exponential. This absolute length exponential growth pattern also occurs in white tilapia larvae using different doses of the thyroxine hormone [12]. This absolute length exponential growth pattern also occurs in white tilapia larvae using different doses of the thyroxine hormone The larval length growth of Rainbow Kurumoi (Melanotaenia parva) for 7 days increased along with the increasing age of the fish [13]. On gift tilapia, the growth performance of fish larvae increased because the larvae were fed with lipid levels of $4.5 \%, 8 \%$ and $11.5 \%$ [14].

The length growth of tilapia larvae at the yolk sac stage (1-5 DAH) was 7.3 $\pm 0.7 \mathrm{~mm}-15.6 \pm 0.4 \mathrm{~mm}$. The growth of the average length of tilapia larvae increased at the yolk sac stage. The yolk sac stage ends on day 7 , when the yolk reserves are almost depleted. The volume of yolk decreases in the larval phase is closely related to the development and growth of larvae [15]. Before the yolk of silver arowana fish runs out, silver arowana fish must be fed to avoid gaps in the utilization of feed from inside and outside, and to increase the growth and morphological development of silver arowana fish larvae [10]. In the preflexion to postflexion stage, the length growth is increasing. The growth in length of larvae increased due to the good use of natural feed.

\subsection{Development of Tilapia Larvae Morphology}

The results of observations regarding the morphological development of tilapia larvae were divided into 4 stages based on the structural development of the body of tilapia larvae (Table 1). The stages of larval development are Yolk sac, preflexion, flexion, and postflexion. Yolk sac stage of Tilapia larvae was on day 1-7 DAH and at this stage the yolk reserves began to run out. The reflexion stage of tilapia larvae was on day 8$14 \mathrm{DAH}$ and at this stage the larvae start to eat natural feed. Tilapia larvae flexion stage was on day 15-20 DAH. Postflexion stage of tilapia larvae was on day 2130 DAH.

Table 1. Stages of morphological development of tilapia larvae (Oreochromis niloticus)

\begin{tabular}{|c|c|c|c|}
\hline No & Stages & $\begin{array}{c}\text { Characteristics of } \\
\text { Morphological Development }\end{array}$ & DAH \\
\hline 1. & $\begin{array}{c}\text { The body was still } \\
\text { transparent. The fins were } \\
\text { not formed, the mouth was } \\
\text { Yolosed, the eyes and skin } \\
\text { were not pigmented, the tip } \\
\text { of the caudal fin was still } \\
\text { rounded, and the dorsal fin, } \\
\text { anal fin and abdominal fin } \\
\text { were undifferentiated. }\end{array}$ & 1-3 \\
\cline { 3 - 4 } & $\begin{array}{c}\text { The body was still } \\
\text { transparent, the mouth began } \\
\text { to open, the eyes began to } \\
\text { become pigmented, the tip of } \\
\text { the caudal fin as still } \\
\text { rounded, the pectoral fins } \\
\text { were formed, while the } \\
\text { dorsal fins, anal fins, and } \\
\text { pelvic fins (abdominal fin) } \\
\text { were undifferentiated }\end{array}$ & 4-7 \\
\hline
\end{tabular}




\begin{tabular}{|c|c|c|c|}
\hline No & Stages & $\begin{array}{c}\text { Characteristics of } \\
\text { Morphological Development }\end{array}$ & DAH \\
\hline 2. & Preflexion & $\begin{array}{c}\text { Yolk reserves were running } \\
\text { out, body organs such as fins } \\
\text { were almost perfect, the } \\
\text { tailbone began to bend. }\end{array}$ & $8-14$ \\
\hline 3. & Flexion & $\begin{array}{c}\text { Pigmentation began to appear } \\
\text { on the head, abdomen and } \\
\text { fins. }\end{array}$ & $15-20$ \\
\hline 4. & $\begin{array}{c}\text { Postflexio } \\
n\end{array}$ & $\begin{array}{c}\text { The dorsal, pectoral, } \\
\text { abdominal and tail fins were } \\
\text { perfect so that the larval } \\
\text { movement was fast. }\end{array}$ & $21-30$ \\
\hline
\end{tabular}

Based on the results obtained from morphological observations of tilapia larvae (Tabel 1), larvae aged 1-3 DAH have a transparent body, fins are not formed, mouth is closed, eyes and skin are not pigmented, the tip of the caudal fin is still rounded, and the dorsal fin, anal fin and abdominal fin are undifferentiated. On the larvae of the Rainbow Kurumoi fish the fins have been formed including the tail fin but the shape is not perfect, the tail and dorsal fins are fused and only the pectoral fins are formed, all fins are perfect and the caudal fin is Cshaped [13]. Nike fish (Awaous melanocephalus) larvae on the first day of hatching have a transparent body, smooth and thin pectoral and dorsal fins, black eye spots adjoining the white part, while on the next day all fins are in the developing phase [4]. On Cyprinus carpio, mouth and the anus does not open, the pectoral fins are formed, and the membranous fins are formed from cephalus top to bottom stomach.

On larvae aged 4-7 DAH has transparent body, the mouth begins to open, the eyes begin to become pigmented, the tip of the caudal fin is still rounded, the pectoral fins are formed, while the dorsal fins, anal fins, and pelvic fins (abdominal fin) undifferentiated. According to [16], on nilem fish (Osteochilus hasselti $C . V$.) which has a transparent body, unpigmented skin, unilobed vesica metatoria, mouth is open, intestine is straight (not filled), the pectoral fin has been formed, the apical end of the caudal fin is still rounded, while the dorsal fin, anal fin and abdominal fin have not been differentiated.

Tilapia larvae on day 8-14 DAH have almost perfect body organs. On day 15-20, pigmentation begins to appear on the head, abdomen and fins of tilapia larvae. On days 21-30, the dorsal, pectoral, abdominal and tail fins of the tilapia larvae are complete so that the larval movement is fast. According to [4], at the postlarva stage, the morphological development of the fish body is complete.

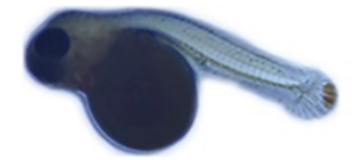

(a)

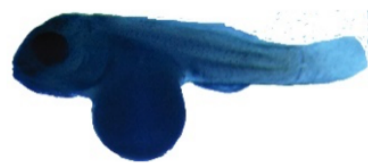

(c)

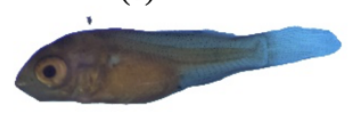

(e) (b)

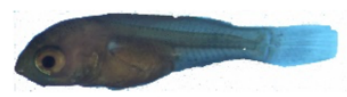

(d)

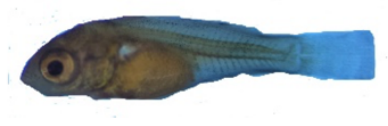

(f)
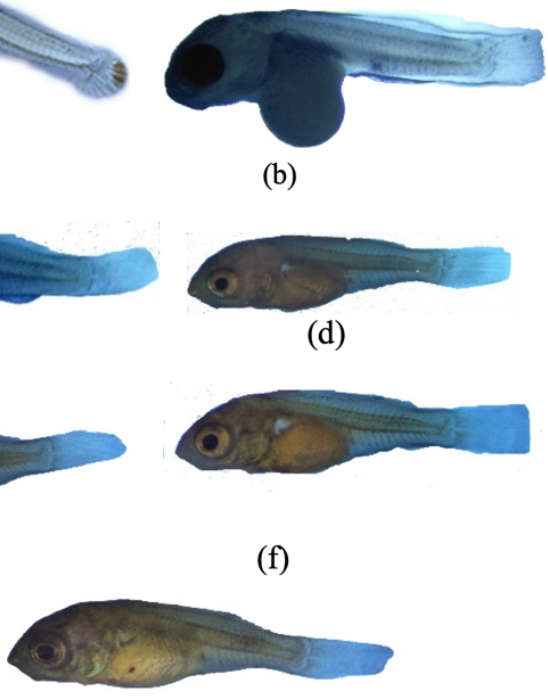

(g)

Fig. 2. Morphological development of tilapia larvae (Oreochromis niloticus). a) $1 \mathrm{DAH}(7,3 \pm 0,7 \mathrm{~mm})$; (b) $5 \mathrm{DAH}$ $(15,6 \pm 0,4 \mathrm{~mm})$; (c) $10 \mathrm{DAH}(20,8 \pm 0,4 \mathrm{~mm})$; (d) $15 \mathrm{DAH}$ $(21,6 \pm 0,8 \mathrm{~mm})$; (e) $20 \mathrm{DAH}(22 \pm 0,6 \mathrm{~mm})$;(f) $25 \mathrm{DAH}(23 \pm 1,6$ $\mathrm{mm})$; (h) 30 DAH $(26 \pm 1,1 \mathrm{~mm})$.

\section{Conclusion}

The length growth of tilapia (Oreochromis niloticus) larvae from 1 DAH to 30 DAH increased along with the increasing age. Tilapia pre-larvae phase on day 1-7 DAH and post-larvae phase on 8-30 DAH. The yolk sac stage occurs at 1-7 DAH, the pre-flexion stage occurs at 8-14 DAH, the flexion stage occurs at 15-20 DAH, and the post-flexion stage occurs at 21-30 DAH.

Acknowledgments. We thank to Mr. Iwan Hasri and all BBI Lukup Badak staff due to their support and assistances during the research. The research was supported by H-Indeks Research grant Number : 169/UN11/SPK/PNBP/2021 tanggal 19 Pebruari 2021.

\section{References}

1. S. Paramadina, J. Triastuti, and A. T. Mukti. Eco. Env. \& Cons. 26 (1) (2020)

2. A. Saifulloh. IOP Conference Series (Earth and Environmental Science). 236(1) (2019)

3. Z. A. Muchlisin. Songklanakarin J. Sci. \& Technol. 35(4) (2013)

4. N. Pasisingi, A. H. Olii, and S. A. Habibie. Tomini J. Aquat. Sci.1(1) (2020)

5. R. Melianawati and R. Pratiwi. J Ris Akuakultur, 6 (1) (2011)

6. D. F. Putra, A. B. Abol-Munafi, Z. A. Muchlisin, and J. C. Chen, Aquaculture, Aquarium, Conservation \& Legislation. 5 (1) (2012)

7. A. H. E. Santo, G. D. Alba, Y. D. S. Reis, L. S. Costa, F. J. S. Vázquez, R. K. Luz, P. A. P. Ribeiro, and J. F. L. Olmeda. Aquaculture $\mathbf{5 2 8}$ (2020) 
8. J. Maithya, N. M. Mbithi and P. Wanjala. Int. J. Fish. Aquac. 9(2) (2017)

9. A. Andriyanto and A. Marzuki. J Ris Akuakultur. 8(1) (2013)

10. Y. W. T. Mulyani, D. D. Solihin and R. Affandi. Jurnal Iktiologi Indonesia. 15(3) (2015)

11. K. D. Hopkins. JWAS. 23 (3) (1992)

12. R. Andriawan, F. Basuki, and T. Yuniarti. Jurnal Sains Akuakultur Tropis. 4 (1) (2020)

13. L. Sholichah. and E Yunita. IOP Conference Series (Journal of Physics. Ser)1097 012035 (2018)

14. J. Qiang, J. He, H. Yang, Y.-L. Sun, Y.-F. Tao, P. $\mathrm{Xu}$, and Z.-X. Zhu. Aquaculture Research 1-14 (2016)

15. T. Kadarini, M. Zamroni, and E. K. Pambayuningrum. Jurnal Riset Akuakultur, 8(1) (2013)

16. D. H. Yusuf, Sugiharto, and G. E. Wijayanti. Scripta Biologica, 1(3) (2014) 